\title{
Local Youth Organization Empowerment to Develop Sustainable Cultural Tourism in Bugbug Traditional Village, Karangasem Regency, Bali
}

\author{
Roels Ni Made Sri Puspa Dewi ${ }^{1}$, Ariqa Nurwilda Sugiarti ${ }^{2}$, Peni Arianita Wardani ${ }^{3}$, \\ Indri Kurniawati ${ }^{4}$, and Hardiman ${ }^{5}$ \\ Sekolah Tinggi Pariwisata Bogor, Bogor Indonesia ${ }^{1}$ \\ Gadjah Mada University, Yogyakarta Indonesia ${ }^{2,5}$ \\ Politeknik Negeri Jember, Indonesia ${ }^{3}$ \\ Sekolah Tinggi Pariwisata Ambarukmo, Yogyakarta Indonesia ${ }^{4}$ \\ \{roelspuspa16@gmail.com ${ }^{1}$ \}
}

\begin{abstract}
Bugbug Traditional Village is one of the old villages in Bali that has unique and sacred ceremonies and traditions. This tradition is one of the attractions for tourists to learn about the culture and see the beauty of this village. The preservation of the culture in Bugbug Traditional Village is inseparable from the role of the young generation embodied in a youth organization called Sekaa Teruna Teruni Dharma Bhakti. This study aims to analyze the empowerment's form of local youth organization and its role to preserve the local culture. Data collected by in-depth interviews with Chairman of Sekaa Teruna Teruni Dharma Bhakti and participation observatory with focus group discussion. Data analyzed by interactive models such as data collection, data reduction, presentation of results, and concluding. The result of this study indicated Sekaa Teruna Teruni Dharma Bhakti has an important role to preserve the cultural traditions that exist in the Bugbug Traditional Village. It also becomes a component of the implementation of cultural customs properly. In addition, the empowerment's form of local youth organization can be seen from their participation as opening and closing traditional ceremonies through sacred dances, playing traditional music, and participating in guiding tourists to provide information about traditional ceremonies.
\end{abstract}

Keywords: Empowerment, Youth Organization, Cultural Tourism

\section{Introduction}

The tourism industry in Bali has developed very rapidly, there are many interesting tourist attractions such as natural, cultural, and heritage attractions. The attractions have developed to be agrotourism, ecotourism and tourism village. Every tourism object in Bali has its uniqueness, especially cultural uniqueness. For example, each village in Bali has its own unique culture, especially in religious ceremonies. Furthermore, the concept of sustainable tourism has been implemented for recent years in Bali. The sustainability of tourism in this area can be seen in 
environmental, economic, social, and cultural aspects. This achievement has been reached because of the good tourism management by local people. Every tourism object in Bali is always managed by a traditional village called Desa Adat or Desa Pakraman. It has very important roles especially in tourism development based on the local community's empowerment. Balinese traditional village consists of several Banjar (local organizations) which are divided by area. Banjar has a very large role in the management of attractions in a traditional village in Bali. Banjar will organize the needs in the development of tourism objects such as: providing facilities, resolving conflicts in tourism objects, and taking care of the sustainability of the attractions.

Every Banjar has a group of youth organizations called Sekaa Teruna Teruni. This organization serves as a forum for the aspirations of young people in the traditional village in Bali. Sekaa Teruna Teruni is a collection or organization of social development organizations for young people who grow and develop based on social awareness and responsibility from the community, especially young people in rural or urban areas engaged in social welfare [1]. Sekaa Teruna Teruni has many roles, especially in terms of preparation for religious ceremonies and maintaining the unity of young people in the village. During this time the contribution of the young generation very low in helping the development of tourism in Bali. Sekaa Teruna Teruni is expected to maintain local knowledge, especially in maintaining the local wisdom of Balinese culture. After being able to maintain local wisdom, it is hoped that Sekaa Teruna Teruni will be more creative and innovative to create new ideas in tourism products following tourist demands.

The role of youth is very important to support the development of the tourism area. The youth are considered as a group of people who have a broad and open insight towards something new or foreign. Therefore, they are expected to become a bridge that can connect local wisdom and the needs of tourists. Analysis of the concept of youth in research views youth as a potential resource and the next generation who are key actors for change in society. Youth generation is Indonesian citizens who enter an important period of growth and development aged 16 to 30 years [2]. Youth empowerment activities must lead to the improvement of skills, guidance, and sharing of experiences from the professional [3]. The creation of responsibilities, authority, and rights of youth in the community is more specifically formed through the participation of youth in every effort to change and develop society, especially about supporting the development of tourism.

\section{Objectives}

The empowerment of the young generation is very important. Empowerment can encourage initiatives and responses so that all problems can be resolved quickly and accurately. Human resources that seek empowerment are easy to do activities because all work patterns are directed towards a responsible attitude. Empowerment is a process that requires thorough planning, deep thinking about monitoring mechanisms, and continuous improvement. Empowerment can be done by revitalizing all resources owned by the organization, including human resources, to provide new energy optimally so that it can be more efficient [4]. The effectiveness role of Sekaa Teruna Teruni supporting tourism in Bali is an important concern to be maximized. From the description, the writer would like to examine the empowerment of the young generation who get involved in Sekaa Teruna Teruni supporting sustainable cultural tourism in Bali. For better understanding, this study focuses on the Sekaa Teruna Teruni Dharma Bhakti that is placed in the cultural tourism village, Bugbug Traditional Village. 


\section{Methods}

This study used descriptive qualitative research methods. The goal of this study is to describe the empowerment of youth generation (Sekaa Teruna Teruni) Dharma Bhakti in Bugbug Traditional Village. Methods of data collection using participation observatory and in-depth interviews, documentation, study literature, and focus group discussion. For determining of the informants using purposive sampling techniques to take key informants from the Chairman of Sekaa Teruna Teruni Dharma Bhakti. Then, for other informants taken with snowball sampling techniques to all members of this organization. Data analyzed by interactive models such as data collection, data reduction, presentation of results, and conclusion [5].

\section{Result}

\subsection{Overview of Bugbug Traditional Village}

Bugbug Traditional Village is located in East Bali. The village is one of the oldest villages in Karangasem Regency. The village is classified as a very large village and has quite a large population. The area of the Bugbug Village covers 815 hectares and surrounded by very beautiful hills. Bugbug is one of the oldest villages in Bali called Bali Aga or Bali Mula. Bali Aga or Bali Mula means the oldest village which is the beginning of the form of a traditional village in Bali. This village has 12 Banjar (local village organizations). Each of these Banjar has its youth organization. The youth organization called Sekaa Teruna Teruni Dharma Bhakti.

This village has many temples besides he Kahyangan Tiga Temple (three fundamental temples) which are common in Bali. These temples are located around the village which is located on a hill, on the coast, in the area of rice fields and the village area. The temples located on the hill are Gumang Temple, Bukit Gundul Temple, and Bukit Pajinengan. The temple which is located in the rice field is Pengalapan Temple. The temples located in the coastal area are Pashujan Temple, Candidasa Temple, and Biaha Temple. The temples located in the village area are Penyarikan Temple, Bebotoh Temple, Pasuwikan Temple, Piit Temple, and Panti Temple.

Bugbug Traditional Village has two tourist attractions such as cultural attractions and natural attractions. Bugbug Village can be categorized as a Spiritual Village where religious practices in carrying out devotional service to God are unique and their frequency is quite numerous. The religious ceremony is commonly called "Usaba". The biggest ceremony in this village is Usaba Manggung and Usaba Gumang. Usaba held once a year and the ceremony celebrating over 3 days. Usaba Manggung takes place in the village area while Usaba Gumang is held in Gumang Temple. Gumang Temple is a temple located on a hill that requires trekking for half an hour to one hour to reach the temple. The temple above is very grand and spacious, from this temple we can see the beauty of Mount Agung Bali and the panorama of the village. In this ceremony, we can see Bugbug Village has so many culture and local tradition.

Natural attractions of Bugbug Traditional Village such as Taman Harmoni Bali and beach. There are two famous beaches in this village including Candidasa Beach and Virgin Beach. Tourism destinations in Bugbug village already equipped with various tourist facilities such as hotels, restaurants, and art shops. 


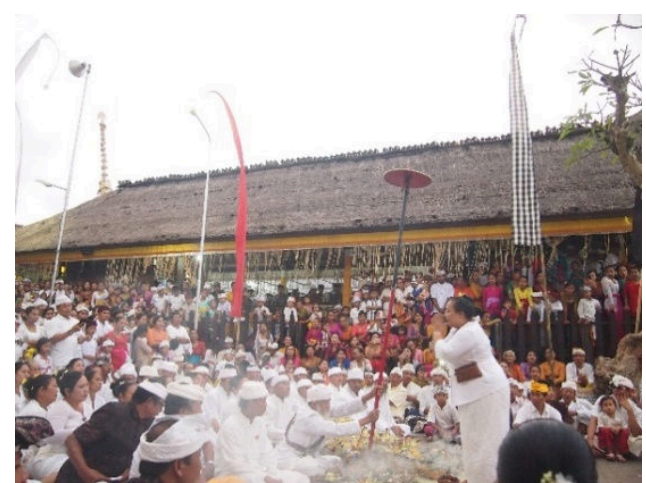

Fig. 1. Usaba Manggung Ceremony

\subsection{Sekaa Teruna Teruni Dharma Bhakti Overview}

Sekaa Teruna Teruni Dharma Bhakti was formed as an organization to shelter young people which existed from 12 Banjar in the Bugbug Traditional Village. The members of Sekaa Teruna Teruni are all young men and women who have entered adolescence and who are not married. Young people have an important role as one element and components of the implementation of traditional ceremonies.

This organization has a role in helping the village in terms of traditional ceremonies. Sekaa Teruna Teruni helps to prepare traditional ceremonies that are often held in the Bugbug Village. Another program that is owned by Sekaa Teruna Teruni is Yowana Mental Spiritual which is a guidance program for young men and women to shape their minds so that it can be based on spiritual principles. In this program, the young generation is taught how to maintain the sacredness of tradition and culture and how to become a good young generation based on God. Other activities carried out by Sekaa Teruna Teruni are working together every month to maintain the cleanliness of the village environment, holding competitions among village youth, and raising funds for nursing homes.

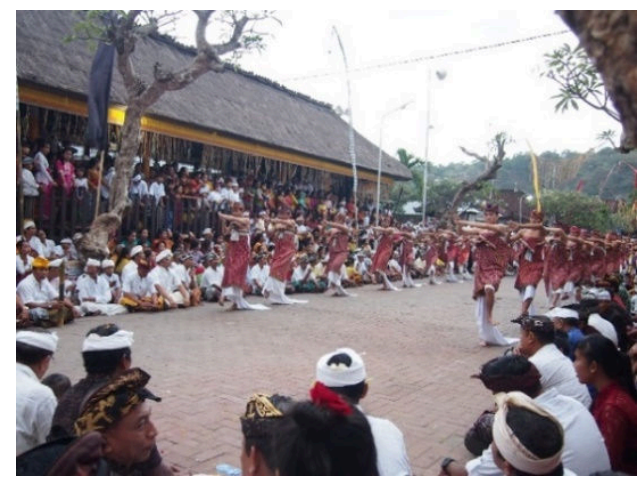

Fig. 2. Role of Sekaa Teruna Teruni Dharma Bhakti (Abuang Dance part of Usaba Manggung ceremony) 


\subsection{Empowerment of Sekaa Teruna Teruni Dharma Bhakti in Cultural Tourism}

Sekaa Teruna Teruni Dharma Bhakti took part in traditional ceremonies in Bugbug Village. Young people have many roles according to the ceremonies. Some of them being as a Pesaren (helping when praying to prepare requirement and give holy water to the local people when come to the temple). When Usaba Manggung and Usaba Gumang ceremonies several young men and women acted as regulators for each ceremony. The men are given names as Teruna Desa, the women are called Teruni Desa. They wear traditional clothes in Bugbug Village. The men wear sarong to the chest level with Kris equipped behind him. The women wear sarong, slendang and Payas Agung (traditional makeup in Bali) decoration on the head. The role of Sekaa Teruna Teruni is to open and close the ceremony with traditional dance. The man dance called Abuang Dance and the women dance called Rejang Dance.

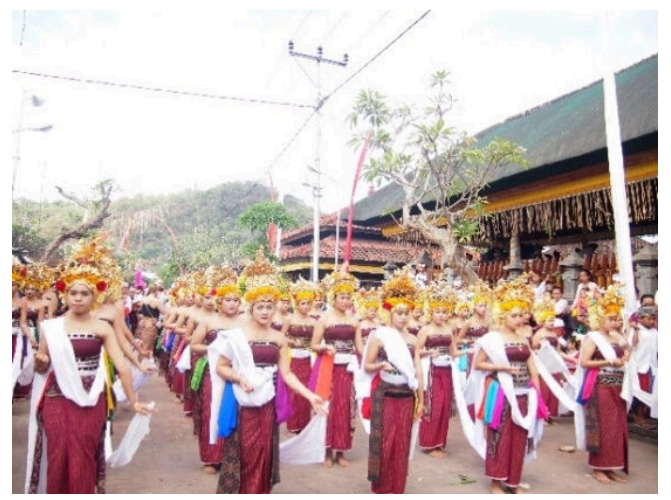

Fig. 3. Rejang Dance

Usaba Gumang and Usaba Manggung have some part of the ceremony. The uniqueness of these two ceremonies is the Sekaa Teruna Teruni make a kind of symbol of the God (pelinggih) called Jempana. This symbol will be carried around the temples and villages. The role of Sekaa Teruna Teruni here is very active, especially in terms of preparing all the needs of traditional ceremonies.

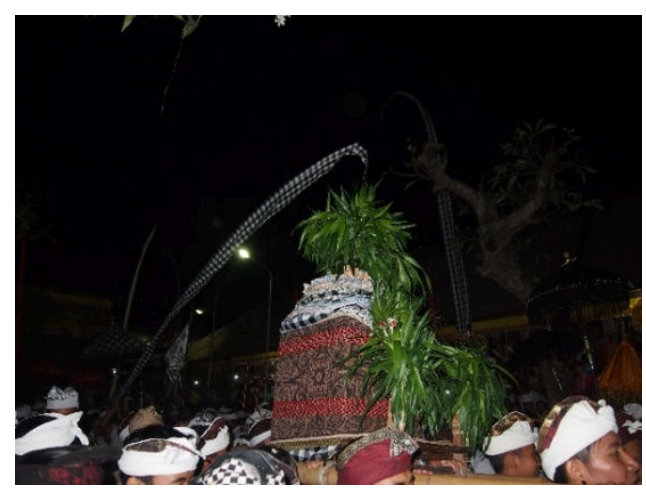

Fig. 4. Jempana 
Sekaa Teruna Teruni also can play traditional music called Gamelan. Gamelan using to company some traditional dance in Bugbug Village. The famous dance in this village called Daretan Dance. The dance occurs because there are local people who entered by the magical power as the implementation of this ceremony.

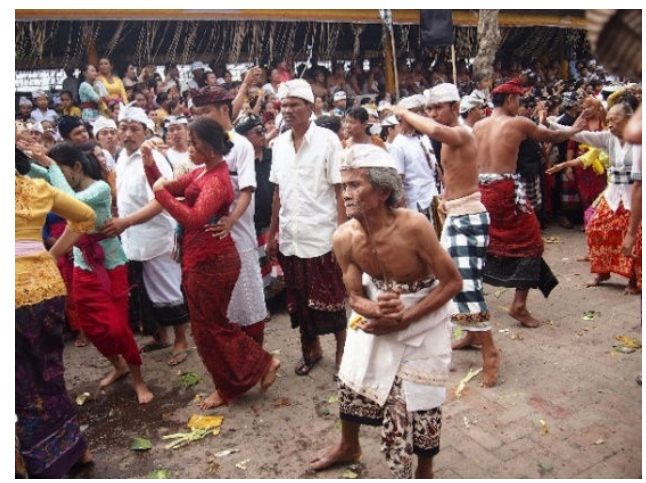

Fig. 5. Daretan Dance

Bugbug Traditional Village has the uniqueness and sacral ceremony make a lot of tourists like to visit this village. Sekaa Teruna Teruni not only has a role in ceremonies but also has a good function in tourism development in Bugbug Village. Some of them as a guide to give information to a tourist when they looking at the biggest ceremony in Bugbug Village. The participation of the young generation in the management of tourism objects such as participating in maintaining the security of attractions together with Pecalang (the person in charge of maintaining village security). The youth will usually stand guard in front of the attractions to maintain the safety and comfort of tourists. In this case, the tourism object that Sekaa Teruna Teruni participated in was the tourism object of the Taman Harmony Bali. Sekaa Teruna Teruni also participates in guarding the entrance ticket to this tourist attraction.

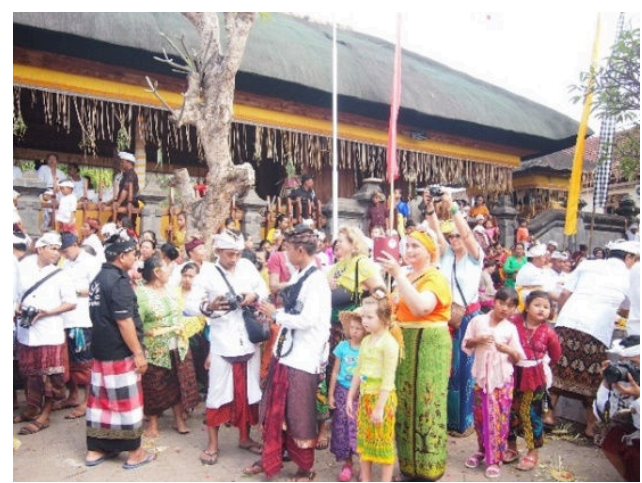

Fig. 6. Foreign Tourist Looking the Ceremony

Bugbug Village as the oldest traditional village in Bali has managed to preserve the uniqueness and sacredness of its ceremonies and traditional traditions. The uniqueness of the existing traditional ceremonies makes many tourists interested in visiting the Bugbug Village. The role of the young generation is very important in maintaining the continuity of traditional customs and culture so that it can survive until now. Sekaa Teruna Teruni not only acts as a 
cultural preserver but also can help develop cultural tourism in the Bugbug Village. The study of locals' attitudes and perceptions young people were included in the context of locals toward tourism greatly contributes to maximize the positive impacts of tourism and minimize its negative impacts [6]. Concerning the empowerment of young people supporting sustainable cultural tourism, youth can provide discoveries and innovative ideas to develop tourism while still maintaining the sustainability of local culture.

Indicators of empowerment success are seen from several aspects involve awareness, willingness, care, increased ability, easy access, problem-solving ability, cooperative attitude, and independence [7]. Empowerment can be said to be successful if a group can be independent and stand-alone in managing a program of activities that are owned. The benefits of empowerment in a place are very beneficial because the results of the activities carried out can be blessed directly by the group. The young generation in Bugbug Village can be empowered properly through the contribution of the youth in preserving the existing customs and culture. Sekaa Teruna Teruni can maintain the existence of traditions and ceremonies so that it can continue to develop into cultural tourism that is in demand by foreign tourists.

\section{Conclusions}

Youth Empowerment of Sekaa Teruna Teruni Dharma Bhakti to develop cultural tourism in the Bugbug Traditional Village has been going well. Sekaa Teruna Teruni has a role as one of the most important components in the implementation of traditions in Bugbug Village. The young generation not only acts to prepare various ceremonial needs but also as a party to be a component to complete the traditional ceremony. Two traditional ceremonies have a very unique and sacred culture namely Usaba Gumang and Usaba Manggung. This ceremony has a different tradition that attracts tourists to looking at this ceremony such as Rejang Dance, Abuang dance, Daretan Dance, and Gamelan traditional music. Sekaa Teruna Teruni as one of the actors who support the sustainability of cultural tourism in the Bugbug Traditional Village. The strengths of the younger generation can encourage tourism in this village to be more developed and innovative. The younger generation can help in terms of promotion and introduce more deeply to tourists through well-developed social media.

\section{Acknowledgements}

The paper was fully funded by Sekolah Tinggi Pariwisata Bogor, Indonesia and partially supported by Local Government and stakholder of Bugbug Village Karangasem Regency, Bali.

\section{References}

[1] Sutama M 2015 Sekaa Teruna-Teruni Sebagai Pilar Mendukung Penegakan Hukum http://www.kompasiana.com/peradah/sekaa-terunateruni-sebagaipilarmendukunpenegakanhukum_552006ec8133113d719de30a

[2] Indonesia P R Undang-Undang RI Nomor. 40 Tahun 2009 tentang Kepemudaan

[3] Dhanani S I and C 2009 A. The Indonesian Labour Market: Changes and Challenges (London: Routledge;)

[4] Sedarmayanti H Membangun dan Mengembangkan Kebudayaan dan Industri Pariwisata (Bunga Rampai Tulisan Pariwisata) (Bandung: PT. Refika Aditama;) 
[5] Miles, B.M. and Huberman A . Analisis Data Kualitatif. (Jakarta: UI-Press;)

[6] Thipsingh S Creating a Network of Youth in Sustainable Tourism Development in the Greater Mekong Sub-region Case study: Nakhon Phanom,Thailand and Khammouan Laos PDR. Procedia - Soc. Behav. Sci. Vol. 195.

[7] Trisnani W T Pemberdayaan Pemuda melalui Program Usaha Ekonomi Produktif oleh Karang Taruna Jayakusuma di Desa Singosaren Banguntapan Bantul. (Universitas Negeri Yogyakarta: Program Studi Pendidikan Luar Sekolah.) 